The Economic and Social Review, Vol. 38, No. 1, Spring, 2007, pp. 135-155

\title{
Inter-Industry Wage Differentials and the Gender Wage Gap: Evidence from European Countries*
}

\author{
BRENDA GANNON \\ National University of Ireland, Galway \\ ROBERT PLASMAN \\ Université Libre de Bruxelles
}

FRANÇOIS RYCX $\dagger$

Université Libre de Bruxelles

Institute for the Study of Labour (IZA), Bonn, Germany

ILAN TOJEROW

Université Libre de Bruxelles

Institute for the Study of Labour (IZA), Bonn, Germany

*This paper is produced as part of a Targeted Socio-Economic Research (TSER) project on Pay
Inequalities and Economic Performance (PIEP) financed by the European Commission (Contract
nr. HPSE-CT-1999-00040) and coordinated by David Marsden (London School of Economics). It
has evolved from earlier versions presented at the 2nd European Association of Labor
Economists/Society of Labor Economists (EALE/SOLE) World conference (San Francisco, June
$2-5,2005$ ) and the 88th Conference of the Applied Econometrics Association (AEA) on the
Econometrics of Labor Demand (Mons, Belgium, October 7-8, 2004). We thank two anonymous
referees for valuable comments. Most of the data used in this study come from the 1995 European
Structure of Earnings Survey. Unfortunately, due to confidentiality issues, this data set is only
available for members of the PIEP research project (http://cep.lse.ac.uk/piep/). Computer
programs used in the analysis are available from the authors upon request. The usual disclaimer
applies.
†Corresponding author: phone: +32 (2) 6504110 , fax: +32 (2) 6503825 , email: frycx@ulb.ac.be 
Abstract: This study analyses the interaction between inter-industry wage differentials and the gender wage gap in six European countries using a unique harmonised matched employeremployee data set, the 1995 European Structure of Earnings Survey. Findings show the existence of significant inter-industry wage differentials in all countries for both sexes. While their structure is quite similar for men and women and across countries, their dispersion is significantly larger in countries with decentralised bargaining. Further results indicate that industry effects on the gender wage gap fluctuate sharply across European countries. In particular, our results show that combined industry effects explain 29 per cent of the gender wage gap in Ireland.

\section{INTRODUCTION}

$\mathrm{T}$ The presence of systematic wage differentials between industrial sectors has been known for many years, and has recently been documented for Ireland (see Gannon and Nolan, 2004). Similarly, the extent of gender wage gaps is well known in many countries, including Ireland (see for example Russell and Gannon, 2002). However, the sources of the gender wage gap among Irish men and women are less obvious. Callan and Wren (1994) were the first to apply decomposition techniques to estimate sources of the gender wage gap. Barrett et al. (2000) applied a similar model, finding that years out of work contributed substantially to differences in male and female wages. Sectoral segregation is another possible source of the gender wage gap - this however was not included in previous research, as the data was not available in a suitable format.

In this paper we propose that industry effects play a major role. To do so, we apply a similar method as the one applied for the United States by Fields and Wolff (1995) and for Belgium by Rycx and Tojerow (2002). The main aim of the paper is to see how industry effects contribute towards the gender gap in European countries, and we compare results from Ireland to those of other countries. The paper estimates the magnitude and dispersion in inter-industry wage differentials for men and women. Moreover, we estimate the proportion of the gender wage gap that may be attributed to industry effects, in terms of either the share of male and female employees per industry and/or difference by gender in the structure of industry wage premia.

The existence of sectoral effects on workers' wages is well documented in the economic literature (Arai et al., 1996; Krueger and Summers, 1988; Lucifora, 1993; Rycx, 2002; Vainiomäki and Laaksonen, 1995). Overall, its existence casts increasing doubt on the assumption of a perfectly competitive labour market. Indeed, it suggests that individual wages are not solely determined by personal productive characteristics and task descriptions but also by the features of the employers in each sector. Nevertheless, many uncertainties remain. One of these derives from the fact that the unobserved 
quality of the labour force might not be randomly distributed among industries. In other words, high-paying industries might simply be those in which the unmeasured labour quality is the highest. Using the 1984 and 1986 Displaced Workers Surveys, Gibbons and Katz (1992) show for the US that the magnitude of the industry wage differentials is almost undiminished when estimating wage equations in first differences rather than in levels. Their findings thus indicate that the workers' sectoral affiliation does matter. The unobserved quality explanation has also been tested by Martins (2004). He rejects the hypothesis that high-wage industries draw disproportionately more on high-ability workers. Therefore, he suggests that non-competitive forces may play an important role in the wage determination process. In contrast, findings of Goux and Maurin (1999) and Abowd et al. (1999) show that individual fixed effects explain a large fraction of the estimated inter-industry wage differentials in France. A similar result has been found by Benito (2000) using individual-level data from the British Household Panel Survey for 1991 and 1994, respectively. All in all, there is no consensus regarding the exact scale of the industry wage premia (Abowd et al., 1999; Björklund et al., 2007; Gibbons and Katz, 1992; Goux and Maurin, 1999). However, there is some agreement on the fact that these effects are fairly persistent, closely correlated from one country to another (Helwege, 1992), and of varying dimensions in the industrialised countries (Hartog et al., 1997).

A number of studies suggest in addition that sectoral effects are significantly weaker in strongly corporatist countries (Edin and Zetterberg, 1992; Hartog, et al. 1997; Kahn, 1998; Rycx, 2003; Teulings and Hartog, 1998; Zanchi, 1992; Zweimüller and Barth, 1994). Cross-country comparisons of inter-industry wage differentials must, however, be considered with caution. The point is that results obtained for different countries are seldom strictly comparable because of differences in the specification of the wage equation, the sectoral nomenclature used, the field covered by the data, or the period under investigation. Moreover, while various explanations based on efficiency wage mechanisms or rent sharing (Benito, 2000; Krueger and Summers, 1988; Lindbeck and Snower, 1990; Thaler, 1989; Walsh, 1999) and job search models (Butters, 1977; Mortensen, 2003; Pissarides, 2000), have been put forward the existence of industry wage differentials remains a complex and unresolved puzzle. ${ }^{1}$

Since Becker's (1957) seminal paper on the economics of discrimination, studies on the magnitude and sources of the gender wage gap have proliferated (Bayard et al., 2003; Blau and Kahn, 2000; Groshen, 1991; OECD

1 These models suggest in particular that differences in wage policy at the firm or industry level may derive from the existence of search frictions, i.e., the incomplete information faced by both employers and workers in the labour market. 
2002). Yet, it is surprising to observe that the evidence regarding the interplay between gender wage gaps and inter-industry wage differentials is limited. The main contribution to this field of study has been provided by Fields and Wolff (1995). Using the 1988 US Current Population Survey, the authors find significant industry wage differentials for women and men, after controlling for productivity-related individual characteristics. These differentials are highly correlated and their dispersion is of the same order of magnitude for both sexes. In spite of these similarities, the authors report significant gender wage gaps within industries. Moreover, their results suggest that around onethird of the overall gender wage gap is explained by industry effects. While thorough and convincing, this study has several shortcomings, especially the standard errors of the inter-industry wage differentials are wrong (HaiskenDeNew and Schmidt, 1997; Reilly and Zanchi, 2003) and the level of significance of the different components of the gender wage gap is not reported (Oaxaca and Ransom, 1998). Furthermore, to our knowledge, the studies of Edin and Richardson (2002) and Rycx and Tojerow (2002), respectively on Sweden and Belgium, provide the only comparable analyses for European countries.

This paper attempts to fill this gap by examining the interaction between the inter-industry wage differentials and the gender wage gap in six European countries, i.e., Belgium, Denmark, Ireland, Italy, Spain, and the UK. To do so, we use a unique harmonised matched employer-employee data set, the 1995 European Structure of Earnings Survey. The contribution of this paper to international literature is significant - as far as we know, this paper is the first to examine with recent techniques, on a comparable basis, and from a European perspective: inter-industry wage differentials by gender, and the contribution of industry effects to the overall gender wage gap. It is also one of the few, besides Kahn (1998), to analyse for both sexes the relationship between collective bargaining characteristics and the dispersion of industry wage differentials.

The remainder of this paper is as follows. Section II describes the data set. Sections III and IV present the methodology and the empirical results. The last section summarises our main findings.

\section{DESCRIPTION OF THE DATA}

The present study is based on the 1995 European Structure of Earnings Survey, gathered by Eurostat. This harmonised survey, covering six European countries, contains a wealth of information, provided by the management of the establishments, both on the characteristics of the latter (e.g. sector of activity, number of workers, level of collective wage bargaining, region) and on 


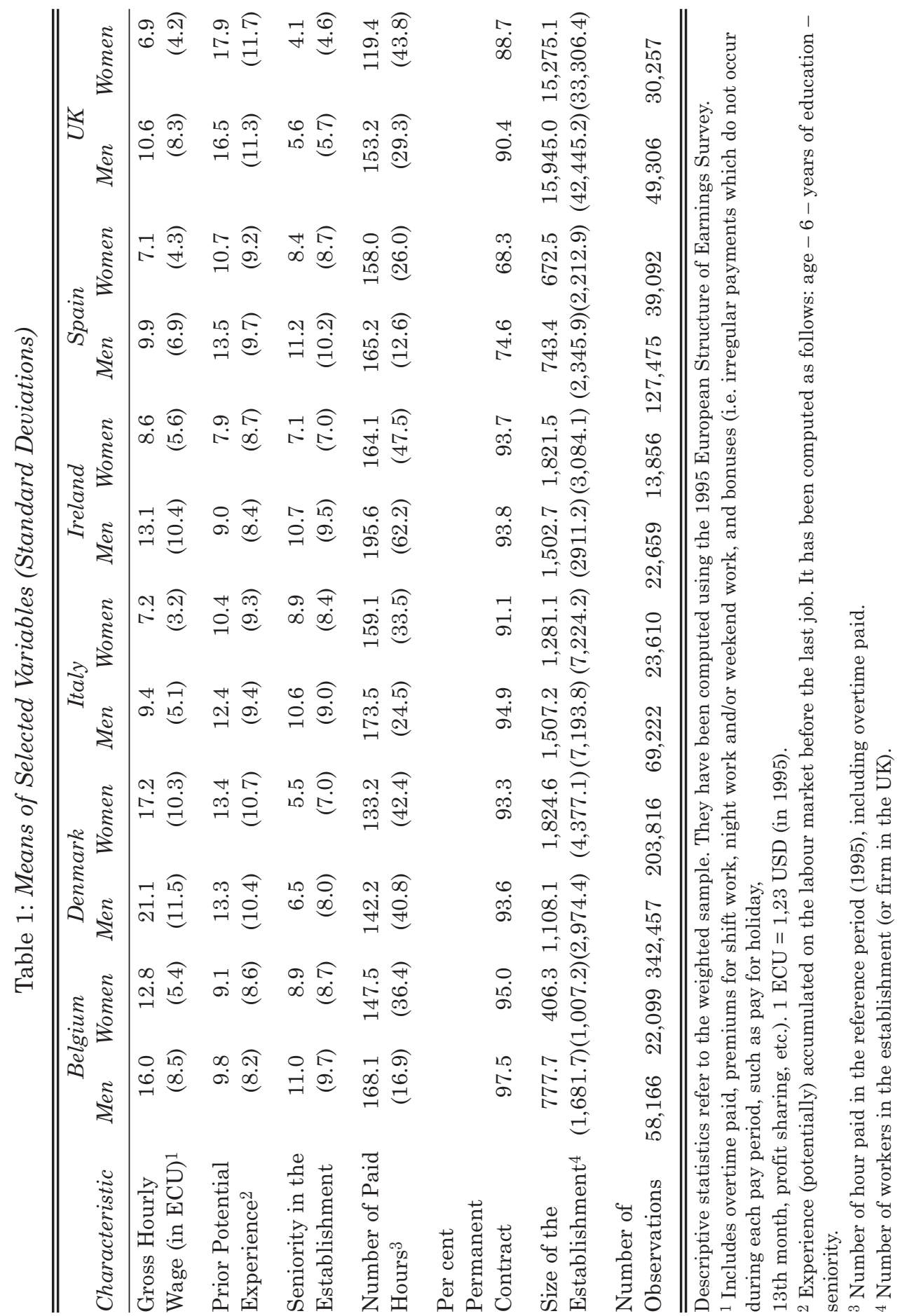


the individuals they employ (e.g. age, level of education, tenure, gross earnings, paid hours, sex, occupation, bonuses). It is representative of all establishments employing at least ten workers and whose economic activities fall within sections $\mathrm{C}$ to $\mathrm{K}$ of the Nace Rev. 1 nomenclature ${ }^{2}$, except for Ireland where sectors F, I and $\mathrm{K}$ are not covered.

Table 1 depicts the means and standard deviations of selected variables for women and men. We note a clear-cut difference between the average characteristics of male and female workers in all countries. The point is that on average men earn significantly higher wages, have more seniority and prior potential experience (except in Denmark and the UK), work a larger number of hours, more frequently have a permanent contract, and are employed in larger establishments (except in Denmark and Ireland). It is interesting to note that the larger gender wage gaps exist in Ireland and the UK, and the lowest in Denmark and Belgium, so we will later on discuss how industry effects may interact with these gaps. First though, we analyse inter-industry wage differentials by gender.

\section{INTER-INDUSTRY WAGE DIFFERENTIALS BY GENDER}

The methodology adopted to estimate the inter-industry wage differentials by gender is consistent with that of Krueger and Summers (1988). However, the standard errors of these differentials have been corrected according to Haisken-DeNew and Schmidt (1997).

For each country and for both sexes, the following semi-logarithmic wage equation has been estimated by ordinary least squares (OLS):

$$
\ln \left(W_{i}\right)=\alpha+\sum_{j=1}^{J} \beta_{j} X_{j, i}+\sum_{k=1}^{K} \psi_{k} Y_{k, i}+\sum_{l=1}^{L} \delta_{l} Z_{l, i}+\varepsilon_{i}
$$

where $\ln \left(W_{i}\right)$ represents the Naperian logarithm of the gross hourly wage of the individual $i ; X$ is the vector of the individual characteristics of the workers and their working conditions (5 indicators showing the highest completed level of education; prior potential experience, its square and its cube; seniority within the establishment and its square; a dummy variable controlling for entrants, i.e. individuals with no seniority; number of hours paid; a dummy for

2 It thus covers the following sectors: i) mining and quarrying (C), ii) manufacturing (D), iii) electricity, gas and water supply (E), vi) construction (F), iv) wholesale and retail trade, repair of motor vehicles, motorcycles and personal and household goods $(\mathrm{G}), \mathrm{v})$ hotels and restaurants $(\mathrm{H})$, vi) transport, storage and communication (I), financial intermediation (J), and vii) real estate, renting and business activities (K). 
extra paid hours; 20 occupational dummies; regional dummies indicating where the establishment is located ${ }^{3}, 3$ dummies for the type of contract, and an indicator showing whether the individual is paid a bonus for shift work, night-time and/or weekend work; $Y$ includes 41 dummy variables indicating the sectoral affiliation of the workers $4 ; Z$ contains employer characteristics (the size of the establishment ${ }^{5}$ and the level of wage bargaining); $\alpha$ is the intercept; $\psi, \beta$ and $\delta$ are the parameters to be estimated; and $\varepsilon_{i}$ is an error term.

Table 2 reports the estimates of the industry wage differentials for male and female workers in six European countries. These are shown as deviations from the employment-weighted mean. Table 2 also records the range and the weighted adjusted standard deviation of the inter-industry wage differentials (WASD).

Results in Table 2 show that, in all countries and for both sexes, wage differentials exist between workers employed in different sectors, even when controlling for working conditions, individual and firm characteristics. Fstatistics reveal that the industry dummy variables are always jointly significant (at the .01 level). Depending on sex and the country considered, we also find that between 57 per cent per cent and 90 per cent of the industry wage differentials are significantly different from zero (at the .10 level). Moreover, we note that the hierarchy of the sectors in terms of wages is quite similar for male and female workers 6 and across countries (see Table 3). Among the best paid sectors, we find the financial sector, the coking, refining and nuclear industry, the tobacco industry, and the production and distribution of electricity, gas, steam and hot water. Furthermore, wages are lowest in the traditional sectors (hotels and restaurants, the textile industry,

\footnotetext{
3 The number of regional dummies is as follows: Belgium (2), Italy (10), Spain (6), and the UK (9). This variable is not available for Denmark and Ireland.

4 Except for Ireland where the number of sectoral dummies is equal to 33 .

5 For the UK, it is the size of the firm.

6 In all countries, Spearman correlation coefficients between male and female industry wage differentials are significant at the .01 level. Their value fluctuates between 71 and $84 \%$.

7 These results could be altered by the inclusion of firm and worker fixed effects. Since a longitudinal data set including the same quality of information is not available at the European level, we cannot use panel data techniques to control for these effects. Yet, we note that several studies still confirm the existence of industry differentials even when individual and firm effects are controlled for. Another option to investigate firm effects relies on the inclusion of dummy variables for each firm in the cross-sectional wage equation (Gannon \& Nolan, 2004). However, results obtained in this way should not be over-interpreted, particularly because there are in some cases only a small number of firms in a given sector in the data. In addition, it is not clear from a theoretical perspective how such firm effects might be interpreted (Goux and Maurin (1999) mention firm size as important, for example, but that is already included separately as a control variable in our model).
} 


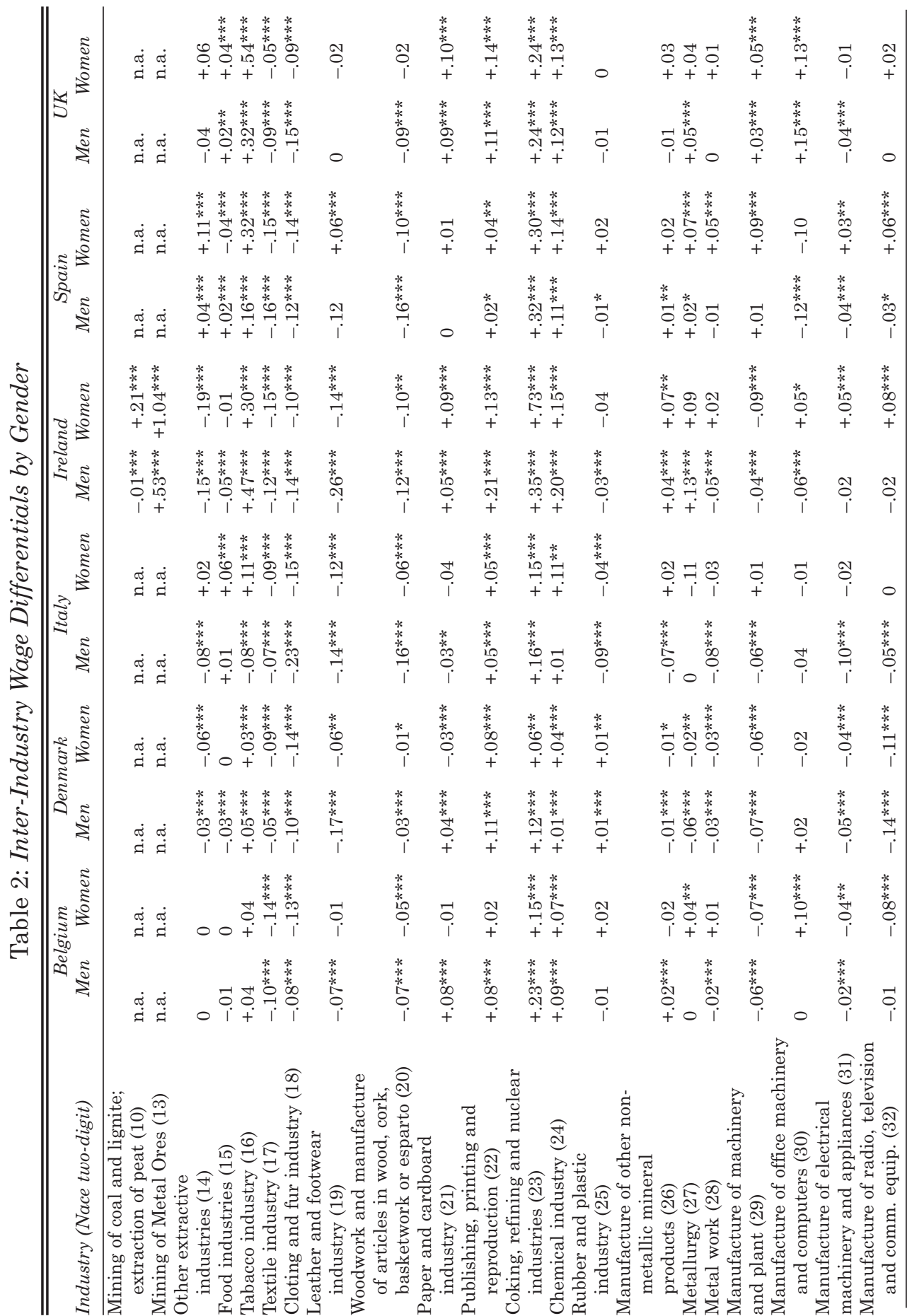




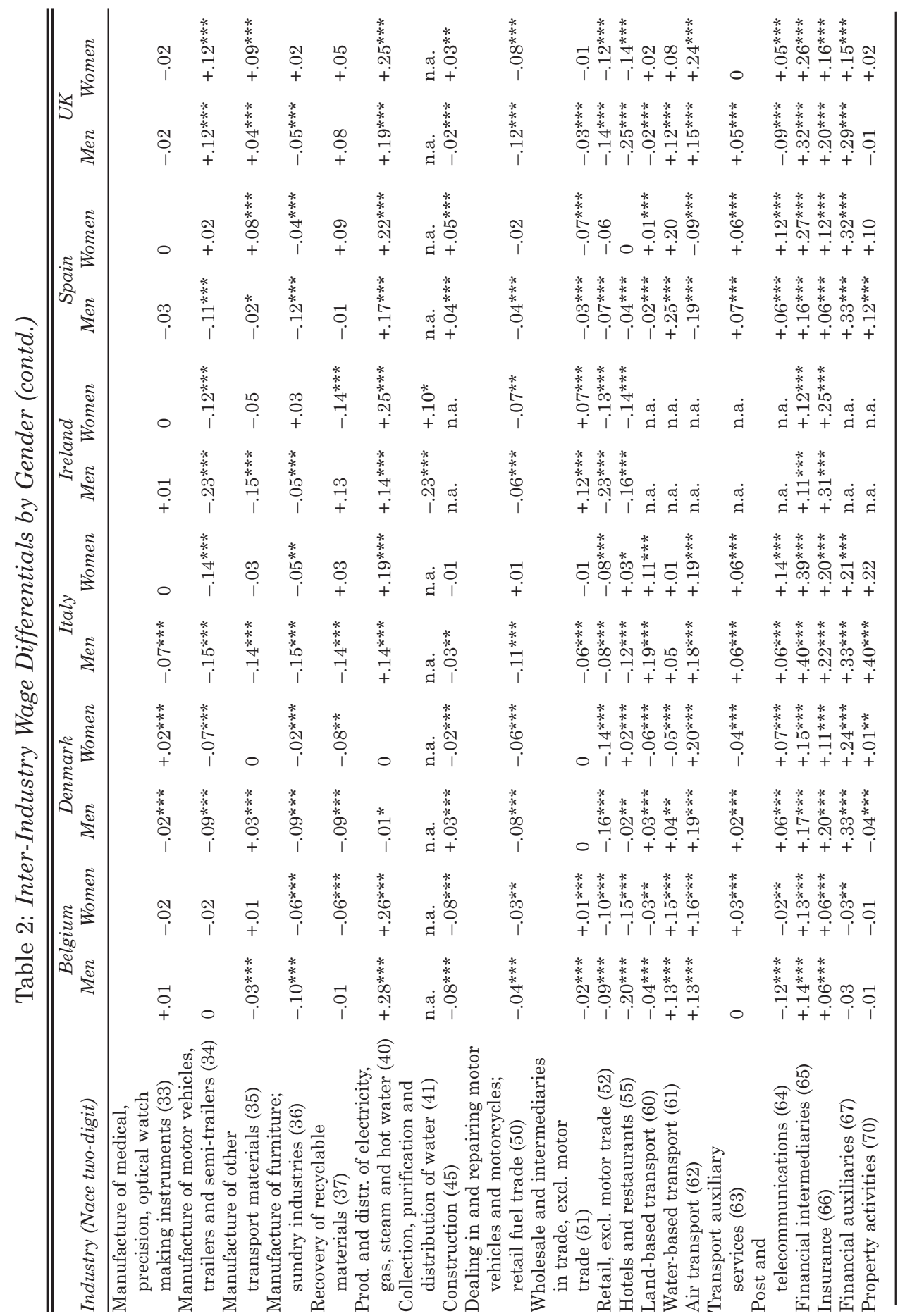




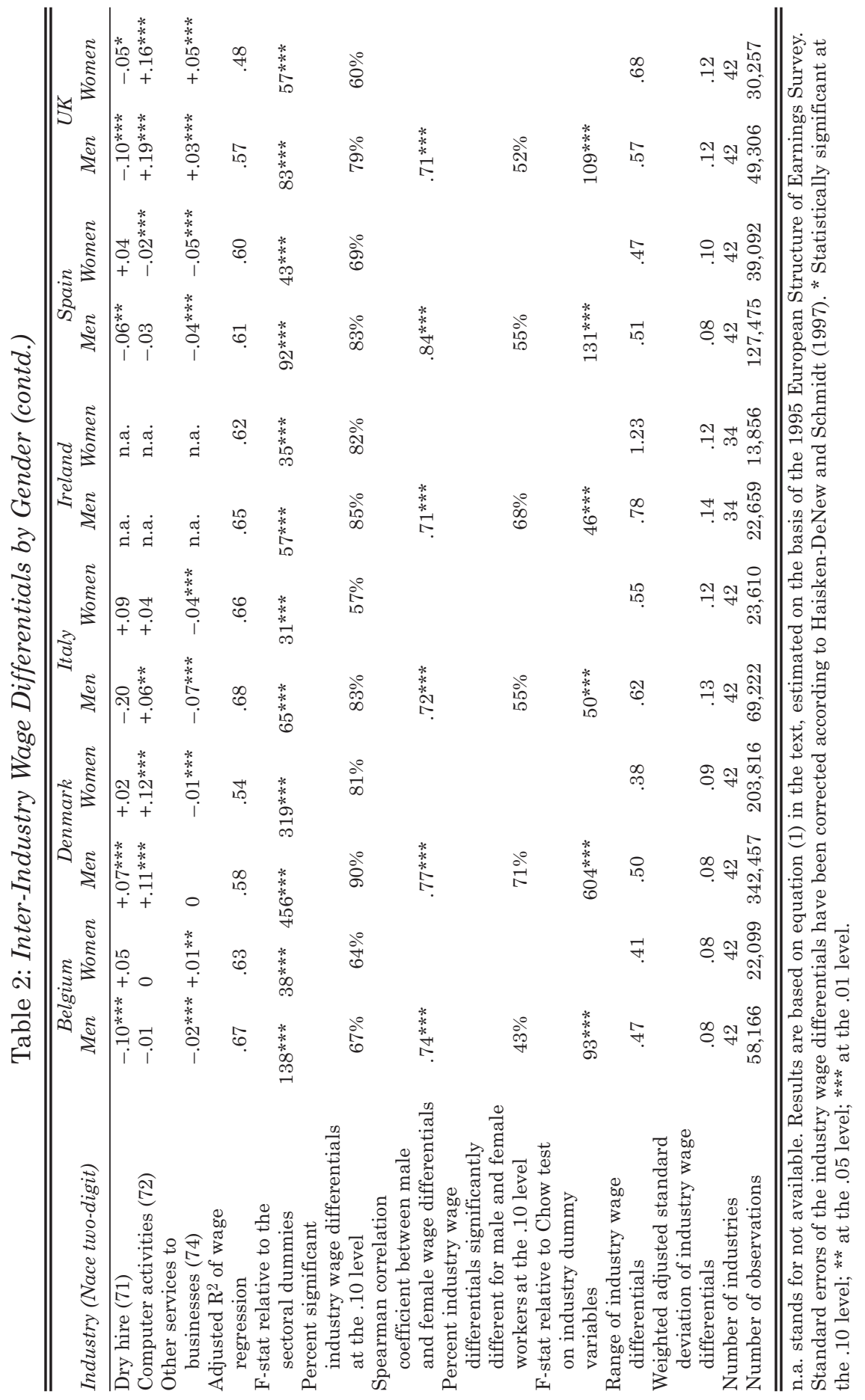


INTER-INDUSTRY WAGE DIFFERENTIALS AND THE GENDER WAGE GAP

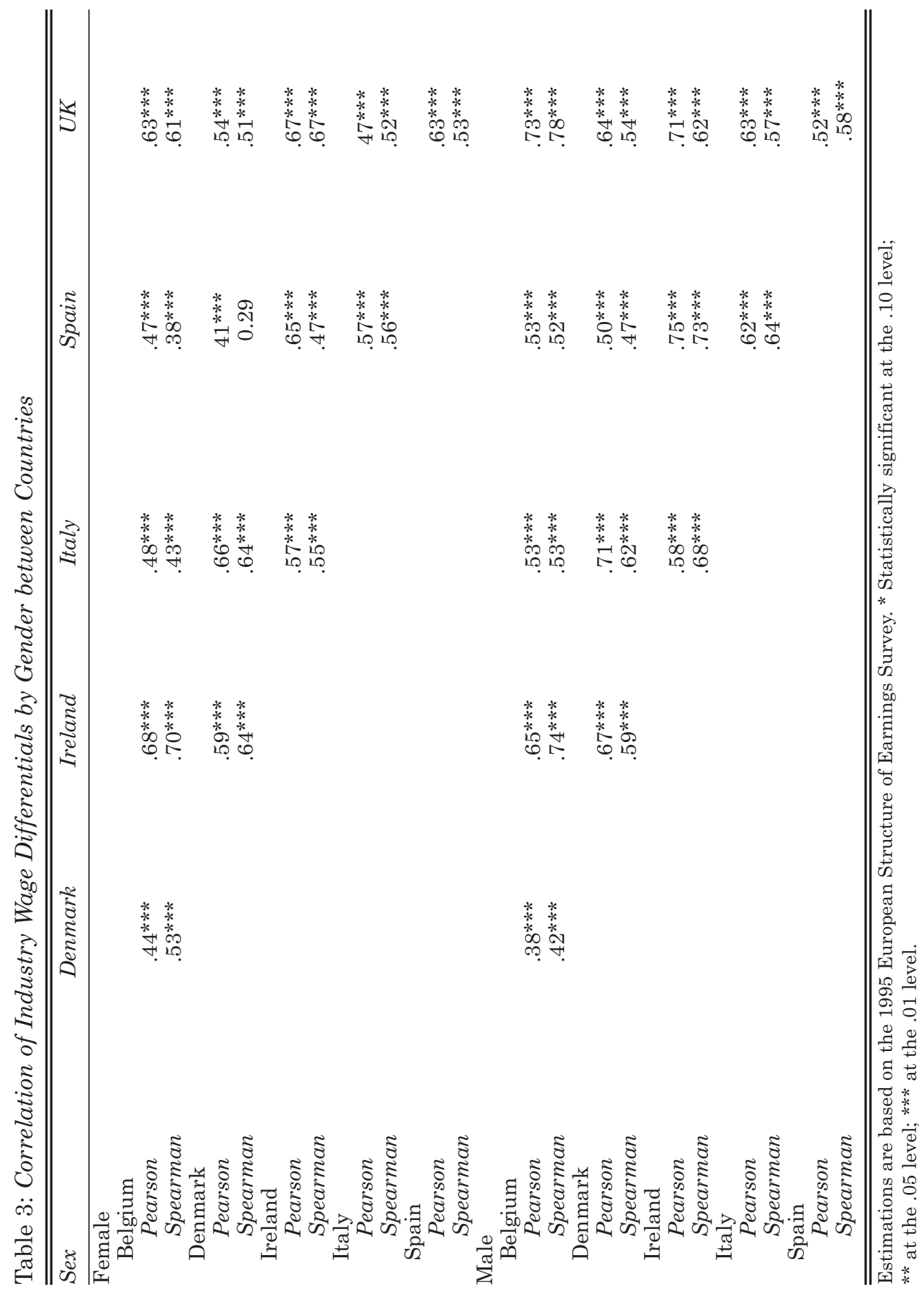


and retailing). ${ }^{7}$ For Ireland, a high proportion of the industry wage differentials is significantly different from zero, and industries with highest wages are similar to those of other countries.

Although the direction of effect is similar for men and women, the magnitudes are not the same in all industries - for example, in Ireland, the differential in the insurance industry is higher for men. A similar effect is found in the UK and Denmark. Indeed, the apparent similarity between industry wage differentials for male and female workers is challenged by standard statistical tests. Indeed, simple t-tests, reported in Table 2, show that between 43 per cent and 71 per cent of the industry wage disparities are significantly different (at the .10 level) for women and men. For Ireland and the UK, this percentage is quite high at 68 per cent and 71 per cent respectively, compared to only 43 per cent in Belgium. Moreover, Chow tests indicate that sectoral wage differentials are significantly different (at the .01 level) as a group for both sexes in all countries.

If we look at the dispersion of industry wage differentials (i.e. the range and the WASD), we find that results vary for men and women, although not systematically nor substantially. A notable exception however is found in Ireland - the range for men is 0.78 and for women is 1.23 . This suggests perhaps that even in the lower paying industries, men are getting higher wages then women. Yet, the dispersion of industry wage differentials fluctuates considerably between countries. For both sexes, we note that the range and the WASD of the industry wage differentials are quite large in Ireland, Italy and the UK, and relatively moderate in Belgium, Denmark and Spain. ${ }^{8}$ Several arguments could be put forward for these differences across

\footnotetext{
8 It is important to note that the data only refer to establishments with 10 or more workers. This limitation may be prejudicial since low pay prevails in small firms (Lucifora et al., 2005). As pointed out by an anonymous referee, which is kindly acknowledged, one might generally expect that inter-industry wage differentials differ by firm size. For instance, smaller firms are likely to have less detailed job descriptions and no seniority-based automatic wage adjustments. This may lead to a smaller bandwidth of wage differences in these firms. Alternatively, there is a large body of empirical evidence supporting the existence of firm size wage differentials (Oi and Idson, 1999; Lallemend et al., 2005). If firms of different sizes are not distributed uniformly over industries, this might bias the results (although the main effects will be picked up by the inclusion of firm size in the wage equation). Overall, whether the omission of small firms leads to an over- or underestimation of the true dispersion of inter-industry wage differentials remains an open question. For example, Rycx (2002) cites results calculated on Dutch data (Loonstructuuronderzoek), that excluding firms with less than 10 employees reduces the dispersion of the industry-wage differentials (estimated for 23 sectors) 6 per cent and 5 per cent for 1996 and 1997 by respectively. These findings suggest that differences in the weighted-adjusted standard deviation due to the omission of small establishments are noteworthly, but not that large. The proportion of all employees working in establishments with less than 10 employees is different across countries, so it is unclear whether this conclusion also holds for Belgium, Denmark, Ireland, Spain, Italy and the UK.
} 


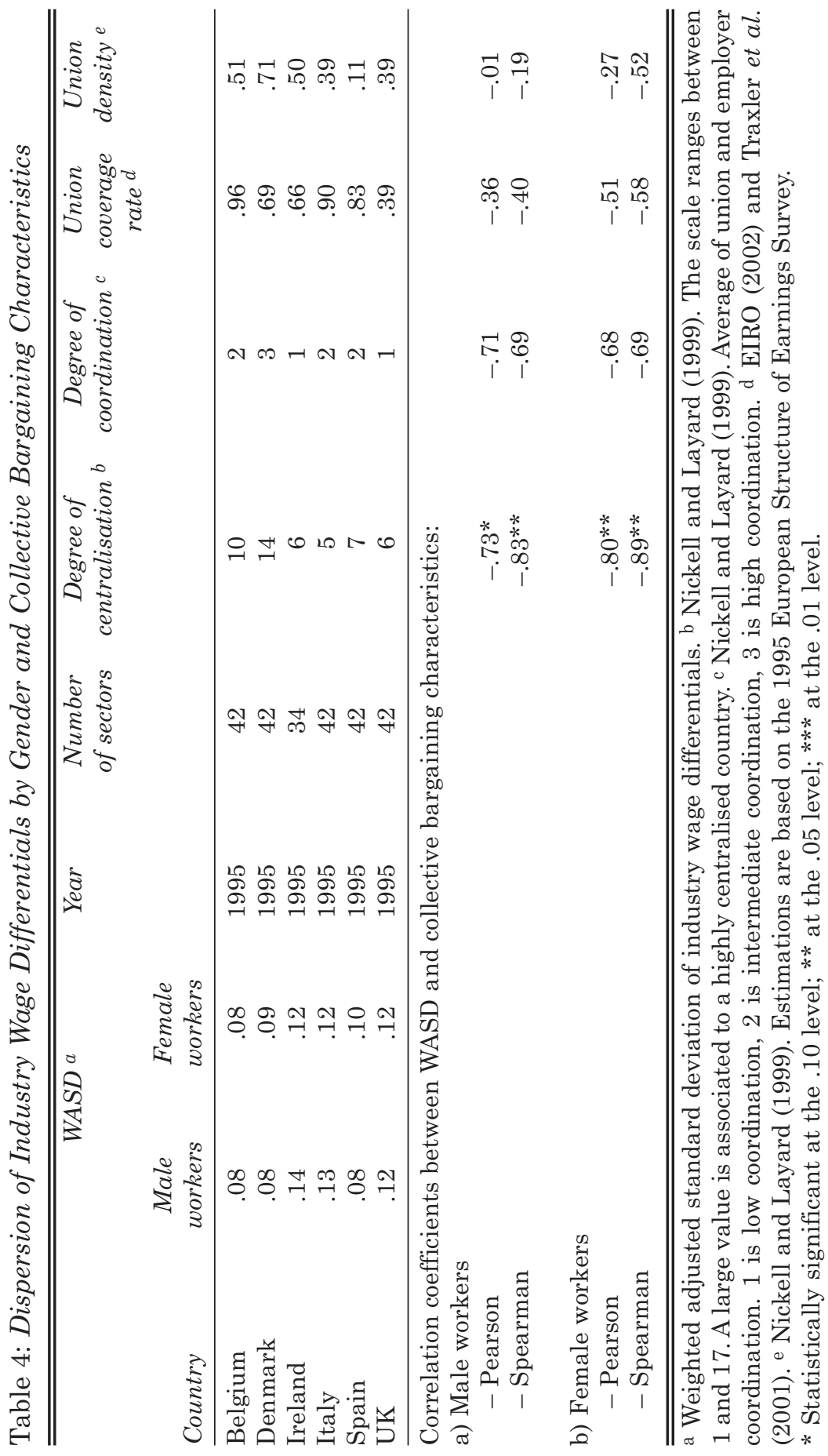


countries. Teulings and Hartog (1998) argued that countries with lower dispersion have a higher degree of corportism. Other characteristics include sectoral union density and level of profitability (Gannon and Nolan, 2004).

Table 4 reports the correlation coefficients between the WASD of the industry wage differentials and collective bargaining characteristics, i.e. the degree of centralisation, the degree of coordination among the social partners, the trade union coverage rate, and trade union density. ${ }^{9}$ For both sexes, results show the existence of a significant (at the .05 level) and negative relationship between the degree of centralisation of collective bargaining and the dispersion of industry wage differentials. In Ireland and the UK, the data reflect much less centralisation compared to Belgium or Denmark, and also show higher dispersion in the former countries. Indeed, results from the simple correlation coefficients suggest that industry wage differentials for male and female workers are more dispersed in countries where wages are essentially bargained at the firm or establishment level. ${ }^{10}$ We should note that the level of corporatism has increased in Ireland since the mid 1980s, but as Gannon and Nolan (2004) note, it is of course questionable whether that could be expected to have a major impact on what were most likely long-standing differentials across industries. Overall though, our results fit in nicely with earlier findings reported by Kahn (1998) for one-digit industries in the U.S. and several European countries (i.e. Austria, Britain, West Germany, Norway and Sweden) in the 1980s.

\section{DECOMPOSITION OF THE OVERALL GENDER WAGE GAP}

To complete our analysis, we have decomposed the overall gender wage gap in order to assess what proportion is due to: (a) differences in the distribution of male and female workers across sectors, (b) differences by

\footnotetext{
9 The degree of centralisation refers strictly to the principal level at which bargaining occurs (establishment, firm, industry or national). In contrast, the degree of coordination among the social partners refers to the ability of trade unions and employers' organisations to coordinate their decisions both horizontally (within a given bargaining level) and vertically (between different bargaining levels). Coordination might be 'overt' or 'covert'. Overt or direct coordination refers to the explicit pursuit of economy-wide coordination goals by the principal bargaining agents (i.e. peak associations of business and labour, possibly joined by the government agencies in tripartite arrangements). In contrast, covert or indirect coordination is achieved through the internal governance of the associations and/or through the pace-setting role of bargaining in key sectors (for a more detailed discussion see, for example, OECD 1997, 2004).

10 Yet, our results should be considered with caution since we do not control for the unobserved individual characteristics of the workers. Indeed, these characteristics might modify our results if it emerged that they were not randomly distributed across sectors, sexes and/or countries. See, for example, Björklund et al. (2007) for results which assign an important role for unmeasured ability.
} 
gender in the structure of industry wage premia, and (c) differences by gender in all other factors, i.e. intercepts, working conditions, individual and firm characteristics. Therefore, we applied the Oaxaca (1973) and Blinder (1973) decomposition technique as follows:

$$
\begin{aligned}
\overline{\ln W_{i}^{m}}-\overline{\ln W_{i}^{f}}= & \sum_{g=1}^{G} \overline{\hat{\lambda}}_{g}\left(\bar{V}_{g}^{m}-\bar{V}_{g}^{f}\right)+\sum_{g=1}^{G} \bar{V}_{g}\left(\hat{\lambda}_{g}^{m}-\hat{\lambda}_{g}^{f}\right)+ \\
& \sum_{k=1}^{K} \overline{\hat{\psi}}_{k}\left(s_{k}{ }^{m}-s_{k}^{f}\right)+\sum_{k=1}^{K} \bar{s}_{k}\left(\hat{\psi}_{k}^{m}-\hat{\psi}_{k}^{f}\right)
\end{aligned}
$$

where the superscripts $m$ and $f$ refer to male and female workers respectively; $\overline{\ln W}$ represents the average (Naperian logarithm) of the hourly wage; $\nabla$ is a vector containing the mean values of the intercept, working conditions, individual and firm characteristics; $s_{k}$ is the share of employment in sector $k$; $\hat{\lambda}$ and $\hat{\psi}$ are the regression coefficients associated respectively to vector $V$ and the industry dummy variables; $\hat{\lambda}_{g}=\left(\hat{\lambda}_{g}^{m}+\hat{\lambda}_{g}^{f}\right) / 2 ; \overline{\hat{\psi}}_{k}=\left(\hat{\psi}_{k}^{m}-\hat{\psi}_{k}^{f}\right) / 2$; and $\bar{s}_{k}=\left(s_{k}{ }^{m}-s_{k} f\right) / 2$.

Table 5: Decomposition of the Overall Gender Wage Gap

Percentage of overall wage gap due to difference in:

$\begin{array}{clcc}\begin{array}{c}\text { Overall Gender } \\ \text { Wage Gap: }\end{array} & \begin{array}{c}\text { Employment } \\ \text { Distribution: }\end{array} & \text { Coefficients: } & \text { Fll other } \\ & \text { Factors: } \\ \left\lfloor\overline{\ln W_{i}^{m}}-\overline{\ln W_{i}^{f}}\right\rfloor & \sum_{k=1}^{K} \overline{\hat{\psi}}_{k}\left(s_{k}{ }^{m}-s_{k}^{f}\right) & \sum_{k=1}^{K} \bar{s}_{k}\left(\hat{\psi}_{k}{ }^{m}-\hat{\psi}_{k} f\right) & \end{array}$

Country

\begin{tabular}{llrrr}
\hline Belgium & .20 & $3.1^{* * *}$ & -.3 .8 & 100.8 \\
Denmark & .18 & $-1.5^{* * *}$ & $14.1^{* * *}$ & 87.4 \\
Ireland & .35 & $8.5^{* * *}$ & $20.1^{* * *}$ & 71.4 \\
Italy & .24 & $15.8^{* * *}$ & -13.6 & 97.8 \\
Spain & .30 & $8.1^{* * *}$ & $-7.8^{*}$ & 99.7 \\
UK & .39 & $7.2^{* * *}$ & -0.4 & 93.2 \\
\hline
\end{tabular}

The level of significance of the different components of the gender wage gaps has been computed according to Oaxaca and Ransom (1998). Estimations are based on the 1995 European Structure of Earnings Survey.

* Statistically significant at the .10 level; ${ }^{* *}$ at the .05 level; $* * *$ at the .01 level. 
Table 5 shows that the overall gender wage gap, measured as the difference between the mean log wages of male and female workers, ranges from .18 in Denmark to .39 in the UK. This means that the average female worker respectively earns between 82 per cent and 61 per cent of the mean male wage. Further results indicate that in all countries a significant (at the .01 level) part of the overall gender wage gap can be explained by differences in the distribution of male and female workers across sectors. Yet, the relative contribution of this factor to the gender wage gap varies substantially among European countries. It is close to zero in Belgium and Denmark, between 7 per cent and 8 per cent in Ireland, Spain and the UK, and around 16 per cent in Italy. Besides, findings suggest that differences by gender in the industry wage premia do not significantly contribute to the overall gender wage gap in Belgium, Italy and the UK. In contrast, these differences would account respectively for 14 per cent and 20 per cent of the gender wage gap in Denmark and Ireland. The result for Spain is more surprising since it is negative and quite substantial (about -8 per cent). However, it should be interpreted with caution since it is only significant at the .10 level. Overall, we find that combined industry effects explain around 29 per cent of the overall gender wage gap in Ireland, respectively around 14 per cent and 16 per cent in Denmark and Italy, around 7 per cent in the UK and almost no share in Belgium and Spain.

Our results for Denmark do not support the conclusion presented by Pedersen and Deding (2000). Indeed, the authors highlight in their paper that the gender wage gap relies primarily in Denmark on the different distribution of male and female employees across sectors, especially on the difference between the public and private sectors. Yet, the exclusion of the public sector in our study may explain why our results differ. On the other hand, our results for Italy are in line with those obtained by Plasman and Sissoko (2004). Both studies highlight the importance of sectoral segregation to explain the Italian gender wage gap.

Our results suggest that of all the countries, the combined industry effects are highest in Ireland, at 29 per cent, with most of this due to gender industry wage differentials. This suggests that in some industries men are getting paid much higher wages than women, and this is after we control for other observed factors such as education, age and experience. Nonetheless, our model does not factor in unobserved effects, either at the individual or firm level and it is likely that most of the industry effects may actually be firm effects. Gannon and Nolan (2004) showed that when a dummy variable for each firm is included into the model, the industry effects disappear. However, the results should be treated with caution as there may be only a small number of firms in each sector. To properly disentangle firm and sector effects, we would require panel data on a large sample of firms and employees. 


\section{CONCLUSIONS}

The main aim of the paper was to estimate how industry effects contribute towards the gender gap in European countries, and we compared results from Ireland to those of other countries. Previous research in Ireland only explored the impact of observed individual characteristics, but in this paper we introduced industry effects and provided a new contribution towards the explanation of the gender wage gap. We have examined the interaction between inter-industry wage differentials and the gender wage gap in six European countries, i.e. Belgium, Denmark, Ireland, Italy, Spain, and the UK. To do so, we have relied on a unique harmonised matched employer-employee data set, the 1995 European Structure of Earnings Survey. As far as we know, this paper is the first to analyse with recent techniques, on a comparable basis, and from a European perspective: i) inter-industry wage differentials by gender and ii) the contribution of industry effects to the overall gender wage gap. It is also one of the few, besides Kahn (1998), to analyse for both sexes the relationship between collective bargaining characteristics and the dispersion of industry wage differentials.

Empirical findings show that, in all countries and for both sexes, wage differentials exist between workers employed in different sectors, even when controlling for working conditions, individual and firm characteristics. We also find that the hierarchy of sectors in terms of wages is quite similar for male and female workers and across countries. Yet, the apparent similarity between male and female industry wage differentials is challenged by standard statistical tests. Indeed, simple t-tests show that between 43 per cent and 71 per cent of the industry wage disparities are significantly different for women and men. Moreover, Chow tests indicate that sectoral wage differentials are significantly different as a group for both sexes in all countries. Regarding the dispersion of the industry wage differentials, we find that results vary for men and women, although not systematically nor substantially. Yet, the dispersion of industry wage differentials fluctuates considerably across countries. It is quite large in Ireland, Italy and the UK, and relatively moderate in Belgium, Denmark and Spain. For both sexes, results point to the existence of a negative and significant relationship between the degree of centralisation of collective bargaining and the dispersion of industry wage differentials.

Finally, results indicate that the overall gender wage gap, measured as the difference between the mean log wages of male and female workers, fluctuates between .18 in Denmark and .39 in the UK. In all countries a significant (at the .01 level) part of this gap can be explained by the segregation of women in lower paying industries. Yet, the relative contribution of this factor to the gender wage gap varies substantially among European countries. It is close to 
zero in Belgium and Denmark, between 7 per cent and 8 per cent in Ireland, Spain and the UK, and around 16 per cent in Italy. Differences in industry wage premia for male and female workers significantly (at the .05 level) affect the gender wage gap in Denmark and Ireland only. In these countries, gender differences in industry wage differentials account for respectively 14 per cent and 20 per cent of the gender wage gap. To sum up, findings show that combined industry effects explain around 29 per cent of the gender wage gap in Ireland, respectively 14 per cent and 16 per cent in Denmark and Italy, around 7 per cent in the UK and almost nothing in Belgium and Spain.

Compared to the other European countries, the gender wage gap is much higher in Ireland. Furthermore, we note that a larger proportion is due to gender differences in industry wage premia. In terms of tackling the gender wage gap in Ireland, this is an important finding. We acknowledge however, that our cross-sectional data did not allow us to model unobserved effects, so our results on the interaction between the gender wage gap and inter-industry wage differentials are not conclusive. Nonetheless, they provide a good basis for cross country comparisons.

In conclusion, our results emphasise that the magnitude of the gender wage gap as well as its causes vary substantially among the European countries. This suggests that no single policy instrument will be sufficient to tackle gender pay inequalities in Europe. Our findings indicate that policies need to be tailored to the very specific context of the labour market in each country.

\section{REFERENCES}

ABOWD, J. M., F. KRAMARZ and D. N. MARGOLIS, 1999. "High Wage Workers and High Wage Firms", Econometrica, Vol. 67, No. 2, pp. 251-333.

ARAI, M., G. BALLOT and A. SKALLI, 1996. "Différentiels intersectoriels de salaire et caractéritiques des employeurs en France”, Economie et Statistique, Vol. 299, pp. 37-58.

BARRETT, A., T. CALLAN, A. DORIS, D. O’NEILL, H. RUSSELL, O. SWEETMAN and J. MCBRIDE, 2000. How Unequal? Men and Women in the Irish Labour Market, General Research Series No. 76, Dublin: The Economic and Social Research Institute.

BAYARD, K., J. HELLERSTEIN, D. NEUMARK and K. TROSKE, 2003. "New Evidence on Sex Segregation and Sex Differences in Wages from Matched Employer-Employee Data”, Journal of Labor Economics Vol. 21, No. 4, pp. 887-922.

BECKER, G. S., 1957. The Economics of Discrimination, Chicago: University of Chicago Press.

BENITO, A., 2000. "Inter-Industry Wage Differentials in Great Britain", Oxford Bulletin of Economics and Statistics, Vol. 62, pp. 727-746. 
BLANCHFLOWER, D. G., A. J. OSWALD and P. SANFEY, 1996. "Wages, Profits and Rent-Sharing", Quarterly Journal of Economics, Vol. 111, No. 1, pp. 227-251.

BLAU, F. and L. KAHN, 2000. "Gender Differences in Pay", Journal of Economic Perspectives, Vol. 14, No. 4, pp. 75-99.

BLINDER, A. S., 1973. "Wage Discrimination: Reduced Form and Structural Variables", Journal of Human Resources Vol. 8, No. 4, pp. 436-465.

BJÖRKLUND, A., B. BRATSBERG, T. ERIKSSON, M. JÄNTTI, and O. RAAUM, 2007. "Inter-Industry Wage Differentials and Unobserved Ability: Siblings Evidence from Five Countries", Industrial Relations, Vol. 46, pp. 727-746.

BUTTERS, G. R., 1977. "Equilibrium Distributions of Sales and Advertising Prices", Review of Economic Studies, Vol. 44, pp. 465-491.

CALLAN, T. and A. WREN, 1994. Male-female Wage Differentials: Analysis and Policy Issues, General Research Series, Paper 163, Dublin: The Economic and Social Research Institute.

EDIN, P.-A. and K. RICHARDSON, 2002. "Swimming with the Tide: Solidary Wage Policy and the Gender Earnings Gap", Scandinavian Journal of Economics, Vol. 104, No. 1, pp. 49-67.

EDIN, P.-A., and J. ZETTERBERG, 1992. "Interindustry Wage Differentials: Evidence from Sweden and a Comparison with the USA", American Economic Review, Vol. 82, No. 5, pp. 1341-1349.

EUROPEAN INDUSTRIAL RELATIONS OBSERVATORY, 2002. "Industrial Relations in the EU Member States and Candidate Countries", Working Paper, European Foundation for the Improvement of Living and Working Conditions.

FIELDS, J. and E. N. WOLFF, 1995. "Interindustry Wage Differentials and the Gender Wage Gap", Industrial and Labor Relations Review, Vol. 49, No. 1, pp. 105-120.

GANNON, B. and B. NOLAN, 2004. "Inter-industry Wage Differentials in Ireland", The Economic and Social Review, Vol. 35, No. 2, pp. 157-182.

GIBBONS, R. and L. F. KATZ, 1992. "Does Unmeasured Ability Explain Interindustry Wage Differentials?", Review of Economic Studies, Vol. 59, No. 3, pp. 515-535.

GOUX, D. and E. MAURIN, 1999. "Persistence of Inter-Industry Wage Differentials: A Reexamination Using Matched Worker-Firm Panel Data", Journal of Labor Economics, Vol. 17, No. 3, pp. 492-533.

GROSHEN, E. L., 1991. "The Structure of the Female/Male Wage Differential: Is it Who You Are, What You Do, or Where You Work?", Journal of Human Resources, Vol. 26, No. 3, pp. 457-472.

HARTOG, J., R. VAN OPSTAL and C.N. TEULINGS, 1997. "Inter-Industry Wage Differentials and Tenure Effects in the Netherlands and the U.S.", De Economist, Vol. 145, No. 1, pp. 91-99.

HELWEGE, J., 1992. "Sectoral Shifts and Interindustry Wage Differentials", Journal of Labor Economics, Vol. 10, No. 1, pp. 55-84.

HAISKEN-DENEW, J. P. and C.M. SCHMIDT, 1997. "Interindustry and Interregion Differentials: Mechanics and Interpretation", Review of Economics and Statistics, Vol. 79, No. 3, pp. 516-521.

KAHN, L. M., 1998. "Collective Bargaining and Interindustry Wage Structure: International Evidence”, Economica, Vol. 65, No. 260, pp. 507-534.

KRUEGER, A. B. and L. H. SUMMERS, 1988. "Efficiency Wages and Inter-Industry Wage Structure”, Econometrica, Vol. 56, No. 2, pp. 259-293. 
LALLEMAND, T., R. PLASMAN and F. RYCX, 2005. "The Establishment-Size Wage Premium: Evidence from European Countries", IZA Discussion Paper 1569.

LINDBECK, A. and D. J. SNOWER, 1990. "Interindustry Wage Structure and the Power of Incumbent Workers", in R. Brunetta and C. Dell' Aringa (eds.), Labour Relations and Economic Performance, London: MacMillan, pp. 378-390.

LUCIFORA, C., 1993. "Inter-Industry and Occupational Wage Differentials in Italy", Applied Economics, Vol. 25, No. 8, pp. 1113-24.

LUCIFORA, C., A. MCKNIGHT and W. SALVERDA, 2005. "Low-wage Employment in Europe: a Review of the Evidence", Socio-Economic Review, Vol. 3, pp. 259-292.

MARTINS, P. S., 2004. "Industry Wage Premia: Evidence from the Wage Distribution", Economics Letters, Vol. 83, pp. 157-163.

MORTENSEN, D. T., 2003. Wage Dispersion: Why Are Similar Workers Paid Differently, Cambridge, MA: MIT Press.

NICKELL, S. and R. LAYARD, 1999. "Labor Market Institutions and Economic Performance", in O. C. Ashenfelter and D. Card (eds.), Handbook of Labor Economics, Vol. 3, No. 46, Amsterdam: Elsevier, pp. 3029-3084.

OAXACA, R. L., 1973. "Male-Female Wage Differentials in Urban Labour Markets", International Economic Review, Vol. 14, No. 3, pp. 693-709.

OAXACA, R. L. and M. RANSOM, 1998. "Calculation of Approximate Variance for the Wage Decomposition Differentials", Journal of Economic and Social Measurement, Vol. 24, No. 1, pp. 55-61.

OECD, 1997. Employment Outlook, Paris: OECD.

OECD, 2002. Employment Outlook, Paris: OECD.

OECD, 2004. Employment Outlook, Paris: OECD.

OI, W. and T. IDSON, 1999. "Firm Size and Wages", in O. Ashenfelter and D. Card (eds.), Handbook of Labour Economics, 3B, Elsevier Science, North Holland, pp. 2165-2214.

PEDERSEN, L. and M. DEDING, 2000. "Wage Differences Between Men and Women in Denmark", Social Research Institute (SFI) Working Paper, 00:4.

PISSARIDES, C. A., 2000. Equilibrium Unemployment Theory. (2nd ed.), Cambridge, MA: MIT Press.

PLASMAN R. and S. SISSOKO, 2004. "Comparing Apples with Oranges: Revisiting the Gender Wage Gap in an International Perspective”, IZA Discussion Papers, 1449.

REILLY, K. T., and L. ZANCHI, 2003. "Industry Wage Differentials: How Many, Big and Significant?", International Journal of Manpower, Vol. 24, No. 4, pp. 367-398.

RUSSELL, H. and B. GANNON, 2002. "The Gender Wage Gap in Ireland", in Impact Evaluation of the European Employment Strategy in Ireland, Dublin: Department of Enterprise, Trade and Employment.

RYCX, F., 2002. "Inter-Industry Wage Differentials: Evidence from Belgium in a CrossNational Perspective", De Economist, Vol. 150, No. 5, pp. 555-568.

RYCX, F., 2003. "Industry Wage Differentials and the Bargaining Regime in a Corporatist Country", International Journal of Manpower, Vol. 24, No. 4, pp. 347-366.

RYCX, F., and I. TOJEROW, 2002. "Inter-Industry Wage Differentials and the Gender Wage Gap in Belgium", Cahiers Economiques de Bruxelles, Vol. 45, pp. 2, pp. 119141.

TEULINGS, C. N. and J. HARTOG, 1998. Corporatism or Competition? Labour Contracts, Institutions and Wage Structures in International Comparison, Cambridge: Cambridge University Press. 
THALER, R. H., 1989. “Anomalies: Interindustry Wage Differentials”, Journal of Economic Perspectives, Vol. 3, pp. 2, pp. 181-93.

TRAXLER, F., S. BLASCHKE and B. KITTEL, 2001. National Labour Relations in Internationalized Markets. A Comparative Study of Institutions, Change, and Performance, Oxford: Oxford University Press.

VAINIOMAKI, J. and S. LAAKSONEN, 1995. "Interindustry Wage Differentials in Finland: Evidence from Longitudinal Census Data for 1975-85”, Labour Economics Vol. 2, No. 2, pp. 161-73.

WALSH, F., 1999. "A Multisector Model of Efficiency Wages", Journal of Labor Economics, Vol. 17, No. 2, pp. 351-376.

ZANCHI, L., 1992. "Inter-Industry Wage Structure: Empirical Evidence for Germany and a Comparison with the U.S. and Sweden", European University Institute Working Paper ECO 92/76, Florence, Italy.

ZWEIMULLER, J., and E. BARTH, 1994. "Bargaining Structure, Wage Determination and Wage Dispersion in 6 OECD Countries", Kyklos, Vol. 47, No. 1, pp. 81-93. 